\title{
Microbial Growth in Soyabean Casein Digest Medium and its Interpretation
}

\section{Sulagna Roy*}

$R$ and D Microbiology, Vadodara, Gujarat, India

*Corresponding Author: Sulagna Roy, R and D Microbiology, Vadodara, Gujarat, India.
Received: July 06, 2021

Published: July 21, 2021

(C) All rights are reserved by Sulagna Roy.

\section{Introduction}

Soybean casein digest medium, also known as Tryptone Soya Broth, is a highly nutritious versatile medium, which is recommended by various pharmacopoeias for sterility testing and microbial limit testing in pharmaceutical industry. It conforms to the harmonized methods of USP/EP/BP/JP/IP requirements. Besides, it is also used for the sensitivity testing by the tube dilution method for antimicrobial agents and also finds use in diagnostic research in microbiology. It is recommended by IP for sterility checking for detection of yeast and moulds.

Pancreatic digest of casein and papaic digest of soyabean meal render this medium nutritious by providing amino acids and long chain peptides for the growth of microorganisms. Natural sugars in soybean favour the growth of fastidious organisms and dextrose monohydrate is the fermentable source of carbon. Dipotassium hydrogen phosphate acts as the buffer in the medium while sodium chloride maintains the osmotic balance of the medium. Upon sterilization, it forms a light yellow coloured clear solution that does not develop any precipitation or sedimentation at room temperature for 7 days [1,2].

Interpretation of growth in SCDM in terms of sterility of test sample

The visual appearance of the SCDM within a few hours after inoculation with the test sample and incubation at 37 degree Celsius indicates the nature of the organism growing predominantly in the medium. This in turn helps in judging the microbial purity of the test sample.
Interpretation of growth in SCDM based on visual appearance

\begin{tabular}{|c|c|c|c|c|}
\hline $\begin{array}{c}\text { Incuba- } \\
\text { tion } \\
\text { temper- } \\
\text { ature } \\
((C)\end{array}$ & $\begin{array}{c}\text { Dura- } \\
\text { tion } \\
\text { (Hours) }\end{array}$ & $\begin{array}{l}\text { Visual appear- } \\
\text { ance of SCDM }\end{array}$ & $\begin{array}{l}\text { Interpreta- } \\
\text { tion }\end{array}$ & $\begin{array}{c}\text { Further } \\
\text { confirma- } \\
\text { tion }\end{array}$ \\
\hline 37 & 24 & $\begin{array}{l}\text { Light yellow } \\
\text { coloured clear } \\
\text { solution }\end{array}$ & $\begin{array}{c}\text { No viable } \\
\text { cells in SCDM } \\
\text { medium }\end{array}$ & $\begin{array}{c}\text { Sterile test } \\
\text { sample }\end{array}$ \\
\hline 37 & 6 to 24 & $\begin{array}{c}\text { Turbidity that } \\
\text { turns SCDM solu- } \\
\text { tion completely } \\
\text { opaque along } \\
\text { with or } \\
\text { without sliminess }\end{array}$ & $\begin{array}{l}\text { Bacteria are } \\
\text { likely to be } \\
\text { present in } \\
\text { test sample }\end{array}$ & $\begin{array}{l}\text { Confirm } \\
\text { the pres- } \\
\text { ence of } \\
\text { bacteria by } \\
\text { micros- } \\
\text { copy }\end{array}$ \\
\hline 37 & 8 to 24 & $\begin{array}{l}\text { Apparently turbid } \\
\text { but closer } \\
\text { observation } \\
\text { shows that there } \\
\text { are minute pel- } \\
\text { lets like poppy } \\
\text { seeds which do } \\
\text { not dissolve into } \\
\text { medium solu- } \\
\text { tion. So medium } \\
\text { solution around } \\
\text { pellets is clear } \\
\text { and separate }\end{array}$ & \begin{tabular}{|} 
Filamentous \\
bacteria/ \\
Actinomy- \\
cetes or fun- \\
gus are likely \\
to be present \\
in test sample
\end{tabular} & $\begin{array}{l}\text { Confirm } \\
\text { the pres- } \\
\text { ence of } \\
\text { Actinomy- } \\
\text { cetes or } \\
\text { fungus by } \\
\text { micros- } \\
\text { copy }\end{array}$ \\
\hline
\end{tabular}




\begin{tabular}{|l|l|c|c|c|}
\hline 37 & 8 to 24 & $\begin{array}{c}\text { No turbidity, clear } \\
\text { solution with } \\
\text { pellets or thick } \\
\text { filament clusters }\end{array}$ & $\begin{array}{c}\text { Filamentous } \\
\text { bacteria/ } \\
\text { Actinomy- } \\
\text { cetes or fun- } \\
\text { gus are likely } \\
\text { to be present } \\
\text { in test sample }\end{array}$ & $\begin{array}{c}\text { Confirm } \\
\text { the pres- } \\
\text { ence of } \\
\text { Actinomy- } \\
\text { cetes or } \\
\text { fungus by } \\
\text { micros- } \\
\text { copy }\end{array}$ \\
\hline 25 & 8 to 24 & $\begin{array}{c}\text { Large spherical } \\
\text { pellets or thick } \\
\text { filament clusters }\end{array}$ & $\begin{array}{c}\text { Fungus are } \\
\text { likely to be } \\
\text { present in } \\
\text { test sample }\end{array}$ & $\begin{array}{c}\text { Confirm } \\
\text { the pres- } \\
\text { ence of } \\
\text { fungus by } \\
\text { micros- } \\
\text { copy }\end{array}$ \\
\hline
\end{tabular}

Table a

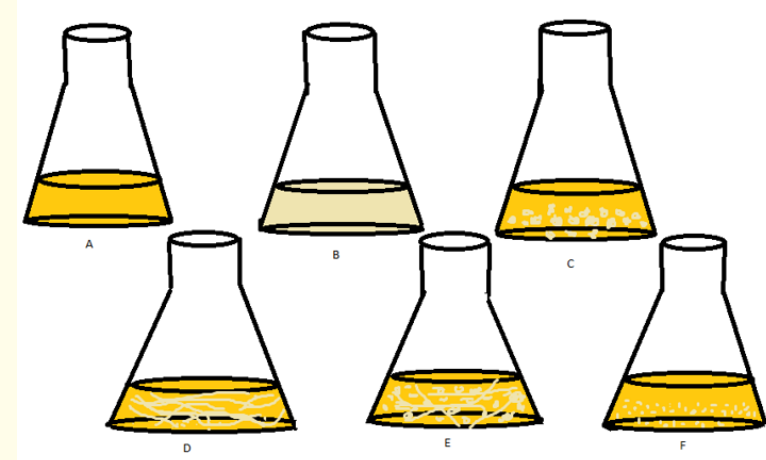

Figure 1: A - appearance of uninoculated SCDM flask or flask with sterile test sample, B - SCDM flask showing turbidity due to bacterial growth, $\mathrm{C}$ - SCDM flask showing large spherical pellets due to fungal growth, D - SCDM flask showing thick filament clusters due to Actinomycetes or fungal growth, E - SCDM flask with pellets and thick filament clusters due to Actinomycetes or fungal growth, F - SCDM flask with poppy seed like pellets due to Actinomycetes or fungal growth.

Interpretation of microscopy of SCDM in terms of sterility of test sample

\begin{tabular}{|l|c|}
\hline \multicolumn{1}{|c|}{$\begin{array}{c}\text { Microscopic observation of } \\
\text { SCDM }\end{array}$} & Interpretation \\
\hline $\begin{array}{l}1 \text {-2 non-motile rods in single } \\
\text { microscopic field }\end{array}$ & Test sample is sterile \\
\hline $\begin{array}{l}1 \text {-2 or 3-4 non-motile rods in } \\
\text { several microscopic fields }\end{array}$ & Test sample may not be sterile \\
\hline $\begin{array}{l}\text { Large number of motile or } \\
\text { non-motile rods }\end{array}$ & $\begin{array}{l}\text { Test sample has bacterial } \\
\text { contamination }\end{array}$ \\
\hline $\begin{array}{l}\text { Large number of motile or } \\
\text { non-motile cocci that are } \\
\text { spherical, all of same } \\
\text { dimensions, rapidly growing } \\
\text { and which appear as perfect } \\
\text { opaque spheres of same size }\end{array}$ & $\begin{array}{l}\text { Test sample has bacterial } \\
\text { contamination }\end{array}$ \\
\hline $\begin{array}{l}\text { Large number of spore bearing } \\
\text { rods or spores that show a } \\
\text { dark periphery and a } \\
\text { transparent or light } \\
\text { transducing core }\end{array}$ & $\begin{array}{l}\text { Test sample has sporulating } \\
\text { bacteria }\end{array}$ \\
\hline
\end{tabular}

Table b

\section{Conclusion}

The major advantage of using SCDM lies in the fact that it permits rapid detection of microbes in the given test sample, within a matter of few hours, even if the microbial load in the test ample is very low. Additionally, its direct visual appearance upon inoculation and incubation is usually sufficient to determine the type of microbe predominantly present in the test sample, thus eliminating the need for individual microscopy of each test sample in most cases. For instance, if a test sample containing 10 individual flasks of an Actinomycetes is to be tested for its purity, then inoculating SCDM from each of these 10 flasks in advance would be helpful in ascertaining the overall purity. In such a case, all SCDM flasks with pure Actinomycetes would show filamentous growth or pellets while those with contamination will appear turbid and opaque. While the purity of any SCDM flask showing ambiguous appearance can be verified using microscopy, this may not be needed for all the flasks with unambiguous appearance and would thus speed up the process of ascertaining purity and sterility.

\section{Bibliography}

1. https://www.himedialabs.com/TD/MM011.pdf 
Microbial Growth in Soyabean Casein Digest Medium and its Interpretation

2. https://www.tmmedia.in/content/soybean-casein-digestmedium-tryptone-soya-broth-caso-broth-uspepjpbp-veg

Volume 4 Issue 8 August 2021

(c) All rights are reserved by Sulagna Roy. 